\title{
EVALUASI EKSTENSIFIKASI DAN INTENSIFIKASI PAJAK SERTA KONTRIBUSINYA DALAM MENINGKATKAN PENERIMAAN PAJAK PENGHASILAN ORANG PRIBADI PADA KPP PRATAMA JAKARTA TANAH ABANG DUA
}

\author{
Maya Safira Dewi; Mirza Maulida \\ Jurusan Akuntansi, Fakultas Ekonomi dan Bisnis, Bina Nusantara University \\ Jln. K.H. Syahdan No. 9, Kemanggisan, Palmerah, Jakarta Barat 11480
}

\begin{abstract}
In 2010, a number of efforts such as the safeguard mechanism has been implemented by the KPP Pratama Jakarta Tanah Abang Dua, one of the safeguard mechanism is an intensification of activity or potential tax starting from the unified tax mapping activities, benchmarking and profiling, with an analysis of the sectors found on the contribution of a region (eg county or city) or the sectors contained in the contribution of tax revenue a tax services office or regional office of the Directorate General of Taxes. Given the working area of KPP Pratama Jakarta Tanah Abang Dua are in the economic and strategic business centers and many residents which don't have tax ID, provide more opportunity for KPP in capturing the public to serve the taxpayer by providing tax ID. But in actual KPP Pratama Jakarta Tanah Abang Dua should be able to read situations and anticipate the various circumstances that might be a problem in the smooth operation of extending the taxpayer, such as mutations in the population without changing the domicile of the candidate statements taxpayers of local authorities and social conditions change.
\end{abstract}

Keywords: extensification, intensification, the taxpayer

\begin{abstract}
ABSTRAK
Di tahun 2010, sejumlah upaya seperti safeguard mechanism sudah diterapkan oleh KPP Pratama Jakarta Tanah Abang Dua, salah satunya dari kegiatan safeguard mechanism adalah intensifikasi pajak atau penggalian potensi pajak terpadu yang dimulai dari kegiatan mapping, benchmarking dan profiling, dengan melakukan analisis terhadap sektor-sektor yang terdapat pada kontribusi suatu wilayah (misal: kabupaten atau kota) ataupun sektor-sektor yang terdapat pada kontribusi penerimaan pajak suatu kantor pelayanan pajak atau kantor wilayah Direktorat Jenderal Pajak. Mengingat wilayah kerja KPP Pratama Jakarta Tanah Abang Dua berada di daerah perekonomian dan sentra usaha strategis serta masih banyak penduduk yang belum berNPWP, memberikan peluang lebih besar bagi KPP dalam menjaring masyarakat untuk dijadikan Wajib Pajak dengan memberikan NPWP. Namun dalam pelaksanaannya KPP Pratama Jakarta Tanah Abang Dua harus dapat membaca keadaan dan mengantisipasi berbagai keadaan yang mungkin akan menjadi masalah dalam kelancaran kegiatan ekstensifikasi Wajib Pajak, seperti mutasi penduduk tanpa keterangan perubahan tempat domisili calon Wajib Pajak dari pihak yang berwenang dan perubahan kondisi sosial masyarakat.
\end{abstract}

Kata kunci: ekstenfikasi, intensifikasi, wajib pajak 


\section{PENDAHULUAN}

Anggaran Pendapatan dan Belanja Negara (APBN) adalah rencana keuangan tahunan pemerintahan Negara Indonesia yang di setujui oleh DPR. APBN berisi daftar sistematis dan terperinci yang memuat rencana penerimaan dan pengeluaran Negara selama 1 tahun anggaran (1 Januari-31 Desember). Direktorat Jenderal Pajak, Fuad Rahmany menyatakan akan berusaha sekeras mungkin agar target bisa terpenuhi. Di sisi lain, penerimaan pajak sangat erat hubungannya dengan penyerapan anggaran setiap tahunnya dan berharap akan lancar pencairan anggaran menjadi $100 \%$. Ekstensifikasi adalah upaya untuk meningkatkan penerimaan pajak dengan menambah jumlah Wajib Pajak yang terdaftar, sedangkan intensifikasi pajak adalah upaya untuk meningkatkan penerimaan pajak dari Wajib Pajak yang sudah terdaftar. Setiap tahunnya Direktorat Jenderal Pajak mentargetkan penambahan jumlah Wajib Pajak dengan jumlah yang cukup besar. Oleh karena itu, ektensifikasi Wajib Pajak perlu diperhatikan khusus, karena perannya yang signifikan dalam meningkatkan penerimaan negara.

Program ekstensifikasi Wajib Pajak dan intensifikasi pajak masih memiliki legitimasi kuat sebagai upaya mendorong pemerimaan pajak. Pemerintah sendiri dalam APBN 2010 telah mentargetkan penerimaan pajak sebesar Rp.733,24 Triliun. Peningkatan penerimaan pajak tercermin dalam Rencana Kerja Pemerintah (RKP) 2011 di mana pemerintah hanya akan mentargetkan defisit anggaran sebesar 1,7\% dan tahun 2012 sebesar 1,4\% - 1,6\%. Berbeda dengan tahun sebelumnya, defisit anggaran pada tahun 2010 berdasarkan APBN-P sebesar 2,1\%. Bila mengalami defisit dalam upaya pembangunan infrastruktur, sumber pembiayaan defisit tesebut dapat di biayai dari 2 sumber yaitu sumber internal (berupa privatisasi atau menngunakan tabungan yang ada atau sisa surplus di tahun sebelumnya dan sumber external yaitu hutang (baik hutang dalam negeri ataupun luar negeri).

Dalam mendukung pencapaian target Rencana Kerja Pemerintah (RKP) 2010 dan 2012 tersebut, pemerintah melakukan serangkaian langkah penting guna mendukung pelaksanaan program ekstensifikasi Wajib Pajak dan intensifikasi pajak. Langkah-langkah tersebut meliputi: (1) penyempurnaan data potensi pajak yang terdiri atas tahapan mapping, profiling, benchmarking, pemanfaatan data potensi pajak pihak ketiga dan optimalisasi pemanfaatan data perpajakan (OPDP); (2) menetapkan sektor properti (perumahan dan apartemen) sebagai perluasan basis pajak; dan (3) law enforcement yaitu program pemeriksaan yang dititikberatkan pada perorangan dan badan hukum serta penagihan pajak berbasis pada tertib administrasi penagihan.

Dalam rangka menambah jumlah Wajib Pajak dan mengejar target penerimaan pajak pasca pelaksanaan program sunset policy, Direktorat Jenderal Pajak perlu melakukan beberapa hal yaitu: (1) melanjutkan kebijakan reformasi perpajakan yang diarahkan pada peningkatan kuantitas dan kualitas aparat pajak yang mampu melayani penambahan 1,4 juta Wajib Pajak orang pribadi (WPOP) baru hingga akhir 2009 dengan baik. Sehingga dengan penambahan ini, Direktorat Jenderal Pajak (DJP) dapat mencapai target perolehan sebesar Rp 7,5 Triliun; (2) merumuskan konsep pemberian insentif dan subsidi lanjutan yang diarahkan pada pembentukan sikap kepatuhan terhadap pajak; (3) memperkecil kepentingan antara Wajib Pajak dengan aparat pajak; dan (4) intensitas dan keseriusan kerja aparat pajak dalam mengejar target pajak yang dibebankan, jangan sampai menimbulkan sikap keterpaksaan para Wajib Pajak dalam membayar kewajiban perpajaknya. Untuk membatasi ruang lingkup pembahasan yang terlalu luas dan sekaligus untuk memperjelas analisis penelitian, maka penelitian ini dibatasi pada pelaksanaan ektensifikasi Wajib Pajak dan intensifikasi pajak, serta kontribusinya terhadap penerimaan pajak pada Kantor Pelayanan Pajak Pratama Jakarta Tanah Abang Dua periode 2008-2010.

Tujuan penelitian yaitu: (1) untuk menjelaskan dan mengevaluasi apakah pelaksanaan ektensifikasi Wajib Pajak dan intensifikasi pajak yang dilakukan oleh Kantor Pelayanan Pajak Pratama Jakarta Tanah Abang Dua pada tahun 2008-2010 telah sesuai dengan peraturan perpajakan; (2) 
mengevaluasi hambatan-hambatan yang dihadapi dalam pelaksanaan ekstensifikasi Wajib Pajak dan intensifikasi pajak oleh Kantor Pelayanan Pajak Pratama Jakarta Tanah Abang Dua; dan (3) mengevaluasi seberapa besar kontribusi dari program ekstensifikasi Wajib Pajak dan intensifikasi Pajak terhadap penerimaan pajak Penghasilan Orang Pribadi pada Kantor Pelayanan Pajak Pratama Jakarta Tanah Abang Dua pada tahun 2008-2010.

Sementara, manfaat penelitian ini yaitu: (1) bagi Penulis, penelitian ini dapat dijadikan bahan studi perbandingan antara kebijakan ketentuan pelaksanaan ekstensifikasi Wajib Pajak dan intensifikasi pajak dalam pelaksanaannya di Kantor Pelayanan Pajak Pratama Jakarta Abang Dua, serta menerapkan pengetahuan teoritis yang telah diperoleh penulis; (2) bagi instansi pajak, hasil penelitian ini diharapkan dapat berguna bagi Direktorat Jenderal Pajak pada umumnya dan KPP Pratama Jakarta Tanah Abang Dua dan pada khususnya, sebagai bahan masukan dalam pengambilan keputusan yang berkaitan dengan pelaksanaan ekstensifikasi Wajib Pajak dan intensifikasi pajak, baik tentang pembuatan peraturan, petunjuk pelaksanaan, penetapan rencana, strategi dan evaluasi kinerja pelaksanaannya; dan (3) bagi pembaca, hasil penelitian ini diharapkan dapat menambah pengetahuan mengenai perpajakan dan memberikan gambaran tentang ekstensifikasi Wajib Pajak dan intensifikasi pajak.

\section{Dasar-dasar Perpajakan Indonesia}

Pengertian pajak menurut Pasal 1 UU No. 28 Tahun 2007 tentang Ketentuan umum dan tata cara perpajakan adalah "kontribusi wajib kepada negara yang terutang oleh orang pribadi atau badan yang bersifat memaksa berdasarkan undang undang, dengan tidak mendapat timbal balik secara langsung dan digunakan untuk keperluan negara bagi sebesar-besarnya kemakmuran rakyat”. Terdapat berbagai jenis pajak, yang dapat dikelompokkan menjadi tiga, yaitu pengelompokkan menurut golongan, menurut sifat dan menurut lembaga pemungutnya. (1) Menurut Golongan, pajak dikelompokkan menjadi dua, yaitu pajak langsung dan pajak tidak langsung. Contoh: Pajak Pertambahan Nilai (PPN) terjadi karena terdapat pertambahan nilai terhadap barang atau jasa; (2) menurut sifat, pajak dikelompokkan menjadi dua, yaitu pajak subjektif dan pajak objektif; dan (3) lembaga pemungut, pajak dikelompokkan menjadi dua, yaitu pajak negara (pajak pusat) dan pajak daerah.

Dalam istilah perpajakan di Indonesia, Ekstensifikasi adalah kegiatan yang dilakukan untuk memberikan Nomor Pokok Wajib Pajak (NPWP) kepada Wajib Pajak Orang Pribadi yang berstatus sebagai pengurus, komisaris, pemegang saham/pemilik dan pegawai, maupun Wajib Pajak Orang Pribadi yang melakukan kegiatan usaha dan/atau memiliki tempat usaha di pusat perdagangan dan/atau pertokoan. Kegiatan Ekstensifikasi ini dilaksanakan oleh Kantor Pelayanan Pajak Pratama melalui Seksi Ekstensifikasi Perpajakan. Jadi, tujuan dari kegiatan ekstensifikasi Wajib Pajak pada dasarnya adalah agar jumlah Wajib Pajak terdaftar pada DJP bertambah, dengan cara mencari subjek pajak yang memenuhi syarat sebagai Wajib Pajak namun belum terdaftar atau mendaftarkan diri sebagai Wajib Pajak. Dasar Peraturannya adalah Per-16/PJ/2007 tentang Pemberian Nomor Pokok Wajib Pajak Orang Pribadi yang berstatus sebagai pengurus, komisaris, pemegang saham/pemilik dan pegawai melalui pemberi kerja/bendaharawan pemerintah.

Ruang lingkup pelaksanaan ekstensifikasi Wajib Pajak yang dilaksanakan oleh Direktorat Jenderal Pajak, sesuai Surat Edaran Dirjen Pajak Nomer: SE - 03/PJ.01/2010 meliputi: (1) pemberian NPWP dan atau pengukuhan sebagai PKP; (2) pemberian NPWP di lokasi usaha termasuk pengukuhan sebagai PKP; dan (3) pemberian NPWP dan atau pengukuhan sebagai PKP. Sasaran utama pelaksanaan ekstensifikasi Wajib Pajak adalah subjek pajak baik orang pribadi, badan maupun BUT yang telah memenuhi syarat sebagai Wajib Pajak, tetapi belum mendaftarkan diri sebagai Wajib Pajak. Data yang digunakan untuk pelaksanaan ekstenskasi Wajib Pajak meliputi data intern dan data ekstern, berdasarkan Surat Edaran Dirjen Pajak Nomor SE-03/PJ./2001. 
Dalam rangka meningkatkan jumlah Wajib Pajak terdaftar dan mengoptimalkan penerimaan pajak, Direktur Jenderal Pajak telah mengeluarkan Surat Edaran Nomor: SE-06/PJ.9/2001 Tentang Pelaksanaan Ekstensifikasi Wajib Pajak dan Intensiflkasi Pajak, yang dimaksud dengan intensifikasi pajak menurut SE-06/PJ.9/2001 adalah kegiatan optimalisasl penggalian penerimaan pajak terhadap objek serta subjek pajak yang telah tercatat atau terdaftar dalam administrasi DJP dan dari hasil pelaksanaan ekstensifikasi Wajib Pajak dan pengertian tersebut dapat diketahui bahwa tujuan utama dari kegiatan intensifikasi pajak adalah optimalisasi penerimaan pajak dari Wajib Pajak yang sudah ada dan Wajib Pajak baru hasil kegiatan ekstensifikasi Wajib Pajak.

Ruang lingkup intensifikasi pajak menurut SE-06/PJ.9/2001 meliputi: (1) penentuan jumlah angsuran pajak penghasilan Pasal 25 dan atau jumlah PPN yang harus disetor dalam tahun berjalan, dimulai sejak Januari sampai dengan akhir tahun yang bersangkutan; (2) Penentuan jumlah PPN yang terutang atas transaksi penjualan dalam tahun berjalan, khususnya untuk PKP Pedagang Eceran yang mempunyai usaha di sentra perdagangan atau perbelanjaan atau pertokoan atau perkantoran atau mal atau plasa dan sentra ekonomi lainnya. Sasaran utama pelaksanaan intensifikasi pajak adalah Wajib Pajak yang telah tercatat atau terdaftar pada administrasi DJP dan Wajib Pajak baru hasil dari kegiatan ekstensifikasi Wajib Pajak. Data yang digunakan untuk pelaksanaan intensifikasi pajak meliputi data intern dan data ekstern yang selengkapnya dapat dilihat pada SE-06/PJ.9/2001.

\section{METODE}

Dalam melakukan penelitian ini, penulis menggunakan metode analisis deskriptif. Penulis mengumpulkan dan menggunakan data-data dari berbagai sumber literatur serta mendeskripsikan dan menganalisisnya untuk memperoleh kesimpulan yang tepat dan sesuai dengan teori yang ada. Dalam melakukan penelitian ini penulis menggunakan dua metode penelitian yaitu penelitian lapangan dan kepustakaan. Dalam metodologi penelitian lapangan, Penulis menggunakan dua teknik pengumpulan data, yaitu: (1) metode pengamatan langsung (observasi), penelitian data dengan melakukan pengamatan langsung atas kejadian atau peristiwa yang berkaitan dengan objek yang diteliti, sehingga diperoleh data yang akurat untuk menunjang landasan data dan fakta serta analisis permasalahan; dan (2) wawancara, melalui metode wawancara, penulis mengajukan pertanyaan secara lisan kepada pihak-pihak yang bersangkutan, dalam hal ini seksi-seksi yang ada di Kantor Pelayanan Pajak, khususnya Seksi Pengolahan Data dan Informasi, Waskon dan Seksi Ekstensifikasi. Metode Penelitian Kepustakaan ini digunakan oleh penulis untuk mendukung landasan teori yang akan dituangkan ke dalam penelitian, maka penulis mengumpulkan data-data yang berasal dari literatur-literatur yang sesuai dengan judul penelitian.

\section{HASIL DAN PEMBAHASAN}

\section{Ruang Lingkup Kegiatan Ekstensifikasi Wajib Pajak dan Intensifikasi Pajak di KPP Pratama Tanah Abang Dua}

Sebagai sumber utama penerimaan Negara, pajak mempunyai peran penting bagi kelangsungan pembangunan saat ini. Oleh karena itu, pajak harus dikelola dengan baik dan benar dengan melakukan langkah-langkah yang tepat dalam mengoptimalisasi potensi pajak yang dimiliki oleh wilayah kerja masing-masing Kantor Pelayanan Pajak dengan meningkatkan jumlah penerimaan Wajib Pajak. Wajib Pajak dibagi menjadi dua, yaitu Wajib Pajak Terdaftar dan Wajib Pajak Efektif. Wajib Pajak Terdaftar adalah Wajib Pajak yang telah terdaftar dalam Tata Usaha Kantor Pelayanan Pajak dan telah diberikan NPWP (Nomor Pokok Wajib Pajak). Sedangkan Wajib Pajak Efektif adalah Wajib Pajak yang memenuhi kewajiban perpajakannya yaitu memenuhi kewajiban menyampaikan SPT Masa dan atau Tahunan sebagaimana mestinya. 
Dalam rangka meningkatkan jumlah Wajib Pajak terdaftar dan mengoptimalkan penerimaan pajak, dipandang perlu untuk menegaskan hal-hal yang berkaitan dengan pelaksanaan Ektensifikasi Wajib Pajak dan Intensifikasi Pajak, yaitu Pajak Penghasilan (PPh) Pasal 25, PPh Pasal 21 dan Pajak Pertambahan Nilai (PPN). Salah satu upaya untuk meningkatkan penerimaan Pajak Penghasilan Orang Pribadi dengan melaksanaan kegiatan Ekstensifikasi Wajib Pajak dan Intensifikasi Pajak yang diatur dalam Surat Edaran Direktur Jenderal Pajak Nomor SE-06/PJ.9/2001 tanggal 11 Juli 2001 tentang tujuan pelaksanaan kegiatan ekstensifikasi dan intensifikasi Pajak Orang Pribadi untuk meningkatkan jumlah Wajib Pajak terdaftar dan mengoptimalkan penerimaan pajak serta Surat Edaran Direktur Jenderal Pajak Nomor SE-113/PJ/2010 tentang penggalian potensi dan pengamanan penerimaan pajak Wajib Pajak orang pribadi baru.

Berdasarkan ketentuan yang terdapat pada Surat Edaran tersebut, Ekstensifikasi Wajib Pajak adalah kegiatan yang berkaitan dengan penambahan jumlah Wajib Pajak terdaftar dan perluasan objek pajak dalam administrasi Direktorat Jenderal Pajak (DJP). Sedangkan intensifikasi pajak adalah kegiatan optimalisasi penggalian penerimaan pajak terhadap objek serta subjek pajak yang telah tercatat atau terdaftar dalam administrasi DJP dan dari hasil pelaksanaan ekstensifikasi Wajib Pajak. Contoh: Account Representative yang mengemban tugas intensifikasi perpajakkan melalui pemberian bimbingan atau himbauan, konsultasi, analisis dan pengawasan terhadap Wajib Pajak, Seksi Penagihan melakukan intensifikasi kegiatan penagihan pajak.

Terdapat beberapa ruang lingkup kegiatan Ekstensifikasi Wajib Pajak dan Intensifikasi Pajak, di antaranya adalah: (1) pemberian Nomor Pokok Wajib Pajak (NPWP) dan atau pengukuhan sebagai Pengusaha Kena Pajak (PKP); (2) pemberian NPWP di lokasi usaha, termasuk pengukuhan sebagai Pengusaha Kena; dan (3) pajak, terhadap orang pribadi pengusaha tertentu yang mempunyai lokasi usaha di sentra perdagangan atau perbelanjaan atau pertokoan atau mall atau plaza atau kawasan industri atau sentra ekonomi lainnya.

Tabel 1 Lokasi Sektor Usaha, Jumlah WP Badan, Peredaran Usaha dan PPh sampai dengan 31 Maret 2010 pada KPP Pratama Jakarta Tanah Abang Dua

\begin{tabular}{llrrr}
\hline \multirow{1}{*}{ Sektor } & \multirow{2}{*}{ Nama Lokasi } & Jumlah & \multicolumn{1}{c}{ Peredaran } & Pembayaran \\
\cline { 3 - 5 } & & \multicolumn{1}{c}{ WP } & \multicolumn{1}{c}{ Usaha* } & \multicolumn{1}{c}{ PPh* $^{*}$} \\
\hline Industri & 352 & 1.024 .815 .608 .910 & 207.409 .794 \\
Perdagangan & PGMTA & 8 & 73.500 .000 & 910.200 \\
& JDC & 69 & 48.258 .207 .068 & 38.445 .719 \\
& Lainnya & 4.005 & 2.465 .017 .326 .457 & 1.755 .253 .178 \\
Pemukiman & & 0 & 0 & 0 \\
Wisata & & 37 & 19.207 .322 .317 & 5.006 .001 \\
Pertambangan & & 112 & 35.911 .291 .526 & 704.858 .923 \\
Perkebunan & & 36 & 37.664 .754 .203 & 9.004 .528 \\
Pertanian & 9 & & \\
Kehutanan & 1 & & \\
Perairan & 3 & & \\
Pelabuhan atau & & & & \\
Bandara & 5 & 3.630 .959 .991 .731 & \\
Pergudangan & 4.715 & & \\
\hline Jumlah & & & \\
\hline
\end{tabular}

Sumber: Data Operational Data Store (ODS)

SPT Tahunan PPh Badan Tahun Pajak per 31 Maret 2010

Data MPN adalah data pembayaran atau penyetoran pajak yang diterima oleh DJP yang telah mendapatkan NTPN (Nomor Transaksi Penerimaan Pajak) dan di lakukan rekonsiliasi oleh DJP. Dengan pertimbangan tersebut KPP Pratama Jakarta Tanah Abang Dua lebih memfokuskan 
pelaksanaan Ekstensifikasi Wajib Pajak dan Itensifikasi Pajak pada para karyawan yang bekerja di perusahaan dalam wilayah kerjanya, pengelola Thamrin Residance, Thamrin City, JDC dan pedagang eceran yang berada di Pusat Grosir Metro Tanah Abang Blok B, serta menjaring calon Wajib Pajak sesuai dengan PER-32/PJ/2010 tanggal 12 Juli 2010. PER-32/PJ/2010 tanggal 12 Juli 2010 merupakan peraturan Direktur Jenderal Pajak (DJP) berisi tentang Pelaksanaan Pengenaan Pajak Penghasilan Pasal 25 bagi Wajib Pajak Orang Pribadi Pengusaha Tertentu.

Berdasarkan ketentuan tersebut KPP Pratama Jakarta Tanah Abang Dua memfokuskan pelaksanaan ekstensifikasi Wajib Pajak dan intensifikasi Pajak pada Wajib Pajak Orang Pribadi yang melakukan kegiatan usaha sebagai Pedagang Pengecer yang mempunyai satu atau lebih tempat usaha dan pedagang eceran Orang Pribadi yang melakukan penjualan barang baik secara grosir maupun eceran dan atau penyerahan jasa melalui suatu tempat usaha. Serta, pemberian NPWP kepada calon Wajib Pajak Orang Pribadi Pengusaha Tertentu yang bertempat usaha serta mempunyai tempat tinggal di kawasan Wilayah Kerja KPP Pratama Jakarta Tanah Abang Dua. Selanjutnya, penulis akan membahas dasar hukum kegiatan ekstensifikasi Wajib Pajak dan intensifikasi pajak yang dilakukan oleh KPP Pratama Jakarta Tanah Abang Dua ke dalam bab pembahasan dan analisis berikutnya.

\section{Dasar Hukum Kegiatan Ekstensifikasi Wajib Pajak dan Intensifikasi Pajak pada KPP Pratama Jakarta Tanah Abang Dua}

Peraturan Direktur Jenderal Pajak Nomor: PER-175/PJ./2006 tanggal 19 Desember 2006 tentang Tata Cara Pemutakhiran Data Objek Pajak dan Ekstensifikasi Wajib Pajak Orang Pribadi yang Melakukan Kegiatan Usaha dan/atau Memiliki Tempat Usaha di Pusat Perdagangan dan atau Pertokoan. Surat Edaran: SE-13/PJ./2007 tanggal 3 April 2007 tentang Penjelasan Peraturan Direktur Jenderal Pajak Nomor: PER-175/PJ/2006 tentang Tata Cara Pemutakhiran Data Objek Pajak dan Ekstensfikasi Wajib Pajak Orang Pribadi yang Melakukan Kegiatan Usaha dan atau Memiliki Tempat Usaha di Pusat Perdagangan dan atau Pertokoan.

Peraturan Direktur Jenderal Pajak Nomor: PER-16/PJ/2007 tanggal 25 Januari 2007 tentang Pemberian Nomor Pokok Wajib Pajak Orang Pribadi yang Berstatus sebagai pengurus, komisaris, pemegang saham atau pemilik dan pegawai melalui pemberi kerja atau bendaharawan pemerintah. Setiap Wajib Pajak Orang Pribadi yang berstatus sebagai Pengurus, Komisaris, Pemegang Saham atau Pemilik dan Pegawai dengan penghasilan di atas PTKP wajib mendaftarkan diri pada KPP dan kepadanya diberikan NPWP. Atas permohonan untuk mendaftarkan diri sebagai Wajib Pajak di KPP Domisili diproses sesuai dengan tata cara pendaftaran yang berlaku. Surat Edaran Direktur Jenderal Pajak Nomor: SE-06/PJ.4/2001 tanggal 21 Februari 2001 tentang intensifikasi Wajib Pajak Pemotongan dan Pemungutan, Khususnya PPh Pasal 21/26.

\section{Pelaksanaan Kegiatan Ekstensifikasi Wajib Pajak dalam Rangka Menambah Jumlah Wajib Pajak Terdafar di KPP Pratama Jakarta Tanah Abang Dua}

Pada akhir tahun 2006 Direktur Jenderal Pajak (DJP) mengeluarkan peraturan untuk memberikan Nomor Pokok Wajib Pajak kepada Wajib Pajak Orang Pribadi yang melakukan kegiatan usaha dan atau memiliki tempat usaha di pusat perdagangan dan atau pertokoan (Peraturan Dirjen Pajak PER- 175/PJ./2006 Pasal 1 nomor 2). Ekstensifikasi Wajib Pajak ini dilaksanakan dengan mewajibkan setiap objek Wajib Pajak, baik pribadi maupun badan, mendaftarkan diri untuk memperoleh Nomor Pokok Wajib Pajak (NPWP) melalui kegiatan ekstensifikasi yang dilaksanakan berdasarkan Peraturan Direktur Jenderal Pajak.

Berdasarkan Surat Edaran Direktorat Jenderal Pajak Nomor SE-13/PJ/2007 tanggal 3 April 2007 tentang Penjelasan Peraturan Direktorat Jenderal Pajak Nomor PER-175/PJ/2006 tentang Tata Cara Pemutakhiran data Objek Pajak dan Ekstensifikasi Wajib Pajak Orang Pribadi yang melakukan kegiatan usaha dan atau tempat usaha di pusat perdagangan dan atau pertokoan sesuai dengan angka 1 
dan 2. Tujuan kegiatan ekstensifikasi adalah untuk pemberian NPWP dengan memperhatikan asas domisili, sedangkan pemenuhan kewajiban perpajakan timbul sebagai akibat pemberian NPWP tetap mengacu pada prinsip self assessment. Sasaran kegiatan ekstensifikasi, agar kegiatan ini harus dilaksanakan secara menyeluruh terhadap setiap gerai atau tempat usaha yang dimiliki, dikuasai dan atau dimanfaatkan oleh Wajib Pajak Orang Pribadi baik yang telah memiliki NPWP maupun belum memiliki NPWP. Bagi Wajib Pajak Orang Pribadi yang telah memiliki NPWP, data dan identitasnya dimutakhirkan sesuai dengan ketentuan. Kegiatan ekstensfikasi dilaksanakan oleh Unit Organisasi dan Petugas Pelaksana Kegiatan Ekstensfikasi. Hal ini tercantum dalam Surat Edaran Direktorat Jenderal Pajak Nomor SE-06/PJ.9/2001 tanggal 11 Juli 2001 tentang Pelaksanaan Ekstensifikasi Wajib Pajak dan Intensfikasi Pajak angka 3 dan 4 adalah sebagai berikut:

Seksi Pengolahan Data dan Informasi (PDI) pada Kantor Pelayanan Pajak (KPP) serta Kantor Penyuluhan Pajak yang berada diluar kota kedudukan KPP. Dalam hal kegiatan ekstensfikasi Wajib Pajak dan intensifikasi pajak dimaksudkan untuk menghitung jumlah pajak yang terutang, kepala KPP dapat menunjuk petugas pada seksi PPh, seksi PPN dan pajak tidak langsung lainnya di KPP untuk diperbantukan pada seksi PDI dan atau Kantor Penyuluhan Pajak. Petugas pelaksana yang melaksanakan kegiatan ekstensfikasi Wajib Pajak dan intensifikasi pajak adalah petugas yang memenuhi kualifikasi sebagai pelaksana kegiatan ektensifikasi Wajib Pajak dan intensifikasi pajak, meliputi: (1) petugas yang ditunjuk oleh Kepala KPP; (2) petugas Kantor Penyuluhan Pajak yang ditunjuk oleh Kepala KPP; (3) petugas lain yang ditunjuk oleh Kakanwil DJP.

Salah satu sumber penting dalam rangka menunjang keberhasilan pelaksanan kegiatan ekstensifikasi Wajib Pajak adalah tersedianya data. Data yang digunakan untuk pelaksanaan kegiatan ekstensifikasi Wajib Pajak dan intensifiksi pajak meliputi data intern dan data ekstern sesuai dengan Surat Edaran Direktur Jenderal Pajak No SE-06/PJ.9/2001 tanggal 11 Juli 2001 pada angka 5, antara lain: (1) pelanggan listrik untuk rumah tinggal dengan daya 6.600 watt atau lebih; (2) pelanggan telefon dengan pembayaran pulsa rata-rata per bulan Rp. 300.000,- atau lebih; (3) pemilik mobil dengan nilai Rp. 200.000.000 atau lebih dan pemilik motor dengan nilai Rp. 100.000.000 atau lebih; (4) pemegang Paspor Indonesia, kecuali pemegang paspor Haji dan pemegang paspor Tenaga Kerja Indonesia (tidak termasuk awak pesawat terbang atau kapal laut); (5) Tenaga Kerja Asing (expatriate) yang bertempat tinggal atau berada di Indonesia lebih dari 183 hari dalam jangka waktu 12 bulan; (6) karyawan kedutaan besar asing atau organisasi internasional; (7) pemilik tanah dan atau bangunan dengan Nilai Jual Objek Pajak (NJOP) 1 milyar atau lebih berdasarkan data kartu jalan atau peta blok atau DHR atau data SPOP; (8) data orang pribadi atau badan selaku penjual atau pembeli tanah dan atau bangunan dari laporan Pejabat Pembuat Akta Tanah (PPAT) atau informasi dari Notaris dengan nilai Rp. 60.000.000 atau lebih; (9) pemilik telepon selular pasca bayar, Pemegang kartu kredit, Pemegang polis atau premi asuransi, Pemegang kartu keanggotaan golf, Artis ,Pemilik atau penyewa ruang, apartemen atau kondominium; (10) pemilik kapal pesiar atau yacht, speed boat, dan pesawat terbang; (11) pemilik saham yang diperdagangkan di pasar bursa; (12) pemilik rumah sewa dan kos; (13) pemegang saham, komisaris, direktur dan penerima dividen; (14) pemilik atau penyewa atau pengguna dan pengelola ruangan pada sentra perdagangan atau perbelanjaan atau pertokoan atau perkantoran atau mal atau plaza atau kawasan atau sentra ekonomi lainnya.

\section{Tata Cara Pelaksanaan Kegiatan Ekstensfikasi Wajib Pajak}

Dalam tahap persiapan kegiatan ekstensifikasi wajib pajak, KPP Pratama Tanah Abang Dua melakukan identifikasi terhadap data yang diperoleh dan mencocokannya dengan data Master File Lokal (MFL) melalui program Sistem Informasi Direktorat Jenderal Pajak (SIDJP). KPP Pratama Tanah Abang Dua membuat daftar norminatif Wajib Pajak yang belum mempunyai NPWP dan atau Surat Pengukuhan Pengusaha Kena Pajak sesuai dengan data yang dimiliki. KPP Pratama Tanah Abang Dua mempersiapkan sarana dan prasarana yang diperlukan. 
KPP Pratama Tanah Abang Dua Melaksanakan koordinasi dengan instansi di luar Direktorat Jenderal Pajak yang terkait dalam pelaksanaan kegiatan ekstensifikasi Wajib Pajak. KPP Pratama Tanah Abang Dua membuat dan mengirimkan Pemberitahuan kepada Wajib Pajak yang terdapat dalam daftar nominative dengan menggunakan formulir untuk Wajib Pajak di wilayah pemukiman dan untuk Wajib Pajak di sentra perdagangan atau perbelanjaan atau pertokoan atau perkantoran, mal, plaza, kawasan industri atau sentra ekonomi lainnya dengan menggunakan surat edaran. Kemudian, melakukan penyisiran (canvassing) yaitu dengan terjun langsung ke lapangan tempat usaha perdagangan di kawasan KPP Pratama Tanah Abang Dua. Serta, melakukan Pemeriksaan Sederhana Lapangan (PSL) dengan pemberian NPWP secara jabatan terhadap pedagang yang memiliki penghasilan di atas Penghasilan Tidak Kena Pajak (PTKP) tetapi tidak kooperatif yaitu tidak mau mendaftarkan diri sebagai Wajib Pajak sesuai dengan petunjuk Surat Edaran Direktur Jenderal Pajak SE-116/PJ/2009 tanggal 21 Desember 2009 tentang Kebijakan Pemeriksaan untuk Tujuan lain.

Dalam tahap pelaksanaan kegiatan ekstensifikasi wajib pajak, berdasarkan Surat Edaran Direktorat Jenderal Pajak Nomor SE-06/PJ.9/2001 tanggal 11 Juli 2001 tentang Pelaksanaan Ekstensifikasi Wajib Pajak dan Intensifikasi Pajak, tertera pada angka 7, 8, 10 dan 11 adalah sesuai dengan tujuan kegiatan ekstensifiasi Wajib Pajak, prioritas utama kegiatan ekstensifikasi Wajib Pajak ditujukan untuk menambah jumlah Wajib Pajak dan Pengusaha Kena Pajak. Atas pemberitahuan yang dikirm kepada Wajib Pajak terdapat beberapa kemungkinan:

1. Wajib Pajak menanggapai dan bersedia untuk mendaftarkan diri dan diberikan NPWP dan dikukuhkan sebagai PKP dengan mengisi formulir pendaftaran. Terhadap Wajib Pajak tersebut dilakukan proses sesuai ketentuan yang berlaku.

2. Wajib Pajak tidak menanggapi pemberitahuan, walaupun pemberitahuan telah diterima. Terhadap Wajib Pajak tersebut akan dilakukan tindak lanjut oleh Seksi Pengolahan Data dan Informasi, yakni data Wajib Pajak tersebut diteruskan ke seksi Pelayanan untuk dilakukan proses pemberian NPWP dan pengukuhan sebagai PKP secara jabatan sesuai dengan tata cara yang sudah ditentukan.

3. Wajib Pajak menanggapi pemberitahuan dengan menyatakan bahwa yang bersangkutan tidak memiliki NPWP atau belum perlu dikukuhkan sebagai PKP. Terhadap Wajib Pajak tersebut akan dilakukan Pemeriksaan Sederhana Lapangan.

4. Wajib Pajak menanggapi pemberitahuan dengan menyatakan bahwa yang bersangkutan sudah memiliki NPWP atau telah dikukuhkan sebagai PKP di KPP lain. Terhadap Wajib Pajak tersebut, dilakukan pencocokan dengan data Master File Lokal

5. Wajib Pajak tidak menanggapi oleh karena pemberitahuan kembali dari Kantor Pos (Kempos). Terhadap Wajib Pajak tersebut, akan dilakukan Pemeriksaan Sederhana Lapangan.

6. Terhadap Wajib Pajak yang melakukan usaha atau dagang di sentra perdagangan atau perbelanjaan atau pertokoaan atau perkantoran atau mall atau plaza atau sentra ekonomi lainnya, seluruhnya dilakukan Pemeriksaan Sederhana Lapangan (PSL).

Dalam rangka pengawasan kegiatan ekstensifikasi Wajib Pajak dan intensifikasi pajak, berdasarkan Surat Edaran Direktorat Jenderal Pajak Nomor SE-06/PJ.9/2001 tanggal 11 Juli 2001 angka 7, 8, 10, 11 agar berjalan sesuai dengan ketentuan yang berlaku, pelaksana kegiatan diwajibkan memonitor pelaksanaan kegiatan tersebut, dengan ketentuan: (1) setiap tim pelaksana kegiatan ekstensfikasi Wajib Pajak, secara berkala membuat laporan hasil pelaksanaan kegiatan ekstensifikasi Wajib Pajak dan intensifikasi pajak untuk dikompilasi oleh Kepala Seksi PDI. (2) Kepala Kantor Penyuluhan Pajak bertanggung jawab atas pelaksanaan kegiatan ekstensfikasi Wajib Pajak dan intensfikasi pajak di wilayahnya dan secara perodik melaporkan hasil kegiatan ekstensifikasi Wajib Pajak dan intensifikasi pajak tersebut kepada kepala KPP. (3) Kepala KPP bertanggung jawab untuk mengawasi pelaksanaan kegiatan ekstensfikasi Wajib Pajak dan intensifikasi pajak tersebut kepada Kakanwil DJP atasannya, dengan menggunakan bentuk laporan. (4) Kakanwil DJP bertanggung jawab untuk mengarahkan dan mengawasi pelaksanaan kegiatan ekstensfikasi Wajib Pajak dan intensifikasi pajak di wilayahnya dan secara periodik melaporkan hasil kegiatan ekstensfikasi Wajib Pajak dan intensifikasi pajak tersebut kepada Direktorat Jenderal Pajak. 


\section{Pelaksanaan Kegiatan Intensifikasi Pajak Terhadap Objek serta Subjek Pajak di KPP Pratama Jakarta Tanah Abang Dua}

Tujuan dari intensifikasi pajak adalah mengintensifkan semua usahanya dalam peningkatan penerimaan pajak, dari sisi ektensifikasi pajak pemerintah melakukan perubahan ketentuan peraturan untuk memperluas cakupan subyek dan objek pajak. Untuk mencapai target tersebut ada tiga strategi yang harus dilakukan, yaitu: (1) membentuk satuan tugas khusus ekstensifikasi dan intensifikasi pajak yang terintergrasi dan bertanggungjawab untuk proses pelaksanaannya; (2) pernyertaan tunjangan khusus untuk seluruh pegawai pajak; dan (3) menumbuhkan semangat rela membayar pajak. Dari ketiga strategi diatas, dapat dilihat bahwa pihak-pihak harus dapat memaksimalkan usahanya untuk mendapatkan serta mencapai target yang telah di tetapkan. Jika ada koordinasi antara pihak yang bertanggung jawab terhadap ekstensifikasi dan intensifikasi pajak, maka usaha untuk mencapai target pajak dapat mudah tercapai. Untuk itu, perlu di tingkatkan kegiatan intensifikasi pajak guna mengoptimalkan penerimaan pajak dari Wajib Pajak yang telah terdaftar sebagai Wajib Pajak. Terdapat tiga Metode yang digunakan untuk kegiatan intensifikasi pajak yang merupakan proses integrasi penggalian potensi pajak terpadu, antara lain: mapping, benchmarking, dan profiling.

Mapping adalah pemetaan yang menggambarkan potensi perpajakan yang dapat dikelompokkan berdasarkan wilayah/lokasi, subjek pajak, jenis pajak, dan sektor/sub sektor usaha, sesuai kebutuhan atau keunggulan yang terdapat di wilayah kerja Kantor Pelayanan Pajak dengan tujuan untuk mendapatkan gambaran umum mengenai potensi perpajakan dan keunggulan di wilayah kerja masing-masing kantor atau unit kerja yang akan digunakan sebagai petunjuk dan sarana analisis dalam rangka penggalian potensi penerimaan, pelayanan dan pengawasan. Pengelompokkan mapping berdasarkan: (1) wilayah administrasi pemerintahan (kelurahan, kecamatan, kabupaten/kota, propinsi); (2) wilayah ekonomi; (3) subjek pajak; (4) jenis pajak; dan (5) sektor atau subsektor. Mapping berguna untuk mengetahui potensi perpajakan dan kelompok-kelompok yang terkait dengan potensi tersebut, tingkat resiko serta petunjuk penggalian potensi yang akan dilakukan. Analisis yang dilakukan dapat berhubungan dengan potensi jumlah Wajib, dengan potensi penerimaan, atau dengan kepatuhan.

\begin{tabular}{lc}
$\begin{array}{r}\text { Tabel } 2 \text { Berhubungan dengan Potensi Jumlah Wajt } \\
\text { Jumlah Penduduk pada } 31 \text { Maret } \\
\text { dengan jumlah Wajib Pajak Orang Priba }\end{array}$ \\
\hline Jumlah KK & 39.358 \\
Jumlah KK Miskin & $(3.050)$ \\
Potensi WP OP & 36.308 \\
Jumlah WP OP Terdaftar & $(31.264)$ \\
Potensi Ekstensifikasi WP & 5.044 \\
\hline
\end{tabular}

Kegunaan mapping untuk memilih kelompok-kelompok yang potensial untuk ditindaklanjuti dengan memperhatikan potensi perpajakannya, tingkat kepatuhannya/tax gap, tingkat kesulitan dalam implementasi, dan deterrent effect. Melalui kegiatan mapping, pimpinan kantor atau unit kerja dapat memperoleh petunjuk (guidance) tentang potensi perpajakan diwilayahnya serta menentukan skala prioritas dari metode penggalian potensi perpajakannya dan selanjutnya dapat mengalokasikan sumber daya secara efektif dan efisien untuk keperluan penggalian penerimaan, pengawasan dan pelayanan kepada Wajib Pajak. 
Kegiatan benchmarking adalah kegiatan penetapan standar ukuran atau besaran yang wajar dan terbaik untuk sektor-sektor usaha tertentu dan digunakan sebagai pembanding untuk menguji kepatuhan wajib pajak yang mempunyai kegiatan usaha yang sejenis dan dijadikan pedoman awal oleh petugas pajak untuk menilai kewajaran dari kegiatan yang dilaporkan wajib pajak. Tujuan kegiatan Benchmarking yaitu menjadi pedoman dan sebagai pembanding dengan kondisi SPT Tahunan yang dilaporkan Wajib Pajak dan membantu pengawasan kepatuhan WP, terutama menyangkut kepatuhan materialnya. Proses dan metode penetapan benchmarking merupakan salah satu langkah strategis yang berkaitan dengan upaya penggalian potensi penerimaan pajak untuk mengamankan penerimaan pajak tahun 2009 dan tahun-tahun selanjutnya.

Program ini merupakan bagian dari program penggalian potensi pajak melalui program mapping, profiling, benchmarking, pertukaran data dan perekaman. Pelaksanaan program tersebut secara teknis dituangkan dalam Keputusan Direktur Jenderal Pajak No. KEP-71/PJ/2009 tentang Pembentukan Tim Pembakuan Disain dan Sistem Aplikasi Mapping, Profilling, Benchmarking, Perekam dan Pertukaran Data Perpajakan, Total benchmarking memiliki karakteristik yaitu: (1) benchmark disusun berdasarkan kelompok usaha; dan (2) benchmarking dilakukan atas rasio-rasio berkaitan dengan tingkat laba dan input-input perusahaan. Gambar 1 menjelaskan alur pemanfaatan total bechmarking.

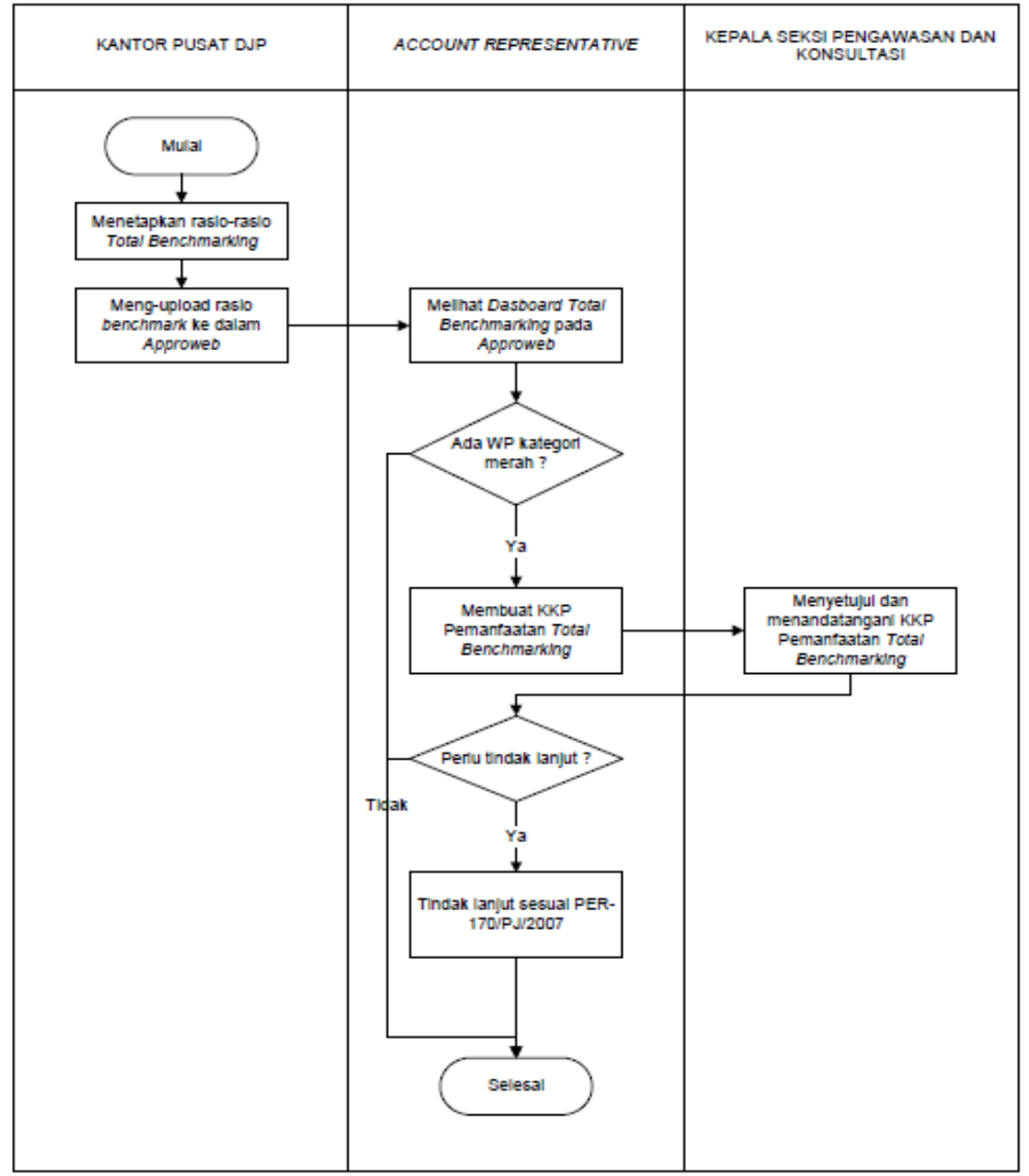

Gambar 1 Alur Pemanfaatan Total Benchmarking

Sumber: PDI KPP Pratama Tanah Abang Dua 
Model alur pemanfaatan benchmarking diatas, diterapkan oleh Kantor Pelayanan Pajak Pratama Tanah Abang Dua dalam rangka melaksanakan fungsinya memberikan bimbingan dan pengawasan terhadap Wajib Pajak. Benchmarking yang dilakukan oleh KPP Pratama Tanah Abang Dua disusun dalam suatu konsep yang disebut Total Benchmarking. Tujuan total benchmarking yaitu menjadi pedoman dan sebagai pembanding dengan kondisi SPT Tahunan yang dilaporkan Wajib Pajak dan membantu pengawasan kepatuhan Wajib Pajak, terutama menyangkut kepatuhan materialnya.Manfaat Total Benchmarking sebagai Supporting tools bagi program intensifikasi atau penggalian potensi pajak dan alat bantu dalam penghitungan tax gap. Total Benchmarking didefinisikan sebagai proses membandingkan rasio-rasio yang terkait dengan tingkat laba perusahaan dan berbagai input dalam kegiatan usaha dengan rasio-rasio yang sama yang dianggap standar untuk kelompok usaha tertentu, serta melihat hubungan keterkaitan antar rasio untuk menilai kewajaran kinerja keuangan dan pemenuhan kewajiban perpajakan Wajib Pajak.

Kegiatan profilling Wajib Pajak adalah rangkaian data dan informasi per Wajib Pajak yang memuat identitas dan kegiatan usaha serta riwayat perpajakan Wajib Pajak secara berkesinambungan dengan tujuan untuk menyajikan informasi yang dapat digunakan pegawai untuk bahan analisis, mengukur tingkat risiko dan kepatuhan Wajib Pajak sehingga pegawai lebih mengenal Wajib Pajak dalam rangka pengawasan, penggalian potensi pajak dan pelayanan yang lebih baik. Adapun, metode lainnya yang digunakan dalam kegiatan intensifikasi pajak adalah aplikasi Optimalisasi Pemanfaatan Data Perpajakan (OPDP) yakni pemanfaatan dan data-matching eksternal dan internal serta program aktivasi Wajib Pajak Non-Filer, yakni upaya tindak lanjut terhadap Wajib Pajak yang tidak menyampaikan SPT.

\section{Hambatan-Hambatan yang Dihadapi}

Kegiatan Ekstensifikasi Wajib Pajak dan intensifikasi pajak khususnya Wajib Pajak Orang Pribadi yang dilakukan oleh KPP Pratama Jakarta Tanah Abang Dua telah berjalan dengan baik, akan tetapi bukan berarti kegiatan tersebut tidak memiliki kendala atau hambatan dalam mencapai hasil yang lebih optimal. Berdasararkan pengamatan langsung yang dilakukan penulis, hambatan yang dihadapi oleh Seksi Ekstensifikasi pajak KPP Pratama Jakarta Tanah Abang Dua adalah sebagai berikut: (1) rendahnya tingkat kesadaran Wajib Pajak; (2) ketidaktahuan Wajib Pajak atas peraturan perpajakan yang berlaku; (3) kesalahpahaman Wajib Pajak dalam menafsirkan peraturan perpajakan; (4) data statistik Wajib Pajak tidak sesuai; (5) Wajib Pajak merasa enggan mendaftarkan diri sebagai WP yang memiliki NPWP karena pajak tidak memberi manfaat langsung kepada masyarakat; (6) sanksi yang ada masih di anggap lebih kecil manfaat ekonomisnya daripada melaporkan diri dan menghitung pajak yang terutang.

\section{Evaluasi Atas Pelaksanaan Kegiatan Ekstensifikasi Wajib Pajak dalam Rangka Menambah Jumlah Wajib Pajak Terdafar di KPP Pratama Jakarta Tanah Abang Dua}

Kegiatan ekstensifikasi Wajib Pajak merupakan upaya yang dilakukan pemerintah dalam rangka meningkatkan penerimaan Negara yang berasal dari pajak. Berdasarkan penelitian penulis, KPP Pratama Jakarta Tanah Abang Dua telah melaksanakan kegiatan ekstensifikasi Wajib Pajak dari tahun 2007 sampai dengan 2010 atas penyisiran lapangan atau canvassing sesuai dengan PER175/PJ./2006 dan PER-16/PJ./2007 terutama atas Wajib Pajak Orang Pribadi. Upaya yang telah dilakukan Kantor Pelayanan Pajak Pratama Tanah Abang Dua untuk proses ekstensifikasi Wajib Pajak sesuai dengan SE-06/PJ.9/2001 adalah: (1) canvassing terhadap pengusaha-pengusaha di sentra-sentra ekonomi, seperti mall, plaza; (2) kerjasama dengan RT/RW/Kelurahan di daerah pemukiman mewah atau masyarakat mampu supaya kepala keluarga diberi Nomor Pokok Wajib Pajak; (3) kerjasama terhadap pihak instansi keimigrasian supaya mewajibkan pemilik paspor untuk memilki Nomor Pokok Wajib Pajak; (4) mewajibkan pemegang kartu kredit memiliki Nomor Pokok Wajib Pajak; (5) mewajibkan pembeli mobil mewah dan rumah mewah memilki Nomor Pokok Wajib Pajak; (6) mewajibkan orang pribadi yang memiliki penghsilan diatas PTKP untuk memiliki NPWP 
Ada beberapa tahapan dalam pelaksanaan kegiatan ekstensifikasi Wajib Pajak, untuk itu penulis akan mengevaluasi hasil pelaksanaan program kegiatan yang telah dilakukan oleh KPP Pratama Tanah Abang Dua.

Dalam PER-175/PJ./2006 tahap persiapan di awali dengan pembuatan rencana kerja yang akan disampaikan ke Kantor Wilayah Direktorat Jenderal Pajak untuk mendapatkan persetujuan meliputi penentuan lokasi ekstensifikasi, dengan satuan kelurahan atau satuan mall/pusat perdagangan, penentuan jumlah Objek Pajak, Pembuatan jadwal pekerjaan dan persiapan administrasi yang meliputi penyediaan SPOP, Lampiran SPOP, Lampiran Pemutakhiran Data Objek Pajak (LPDOP), Peta Blok, Blanko Kartu NPWP dan dokumen lain yang diperlukan. Berdasarkan pengamatan dan hasil wawancara penulis dengan Petugas Ekstensifikasi dan Waskon dapat disimpulkan bahwa tahap perencanaan kegiatan ekstensifikasi yang dilakukan KPP Pratama Jakarta Tanah Abang Dua telah dilakukan sesuai dengan peraturan pelaksanaan.Kegiatan ekstensifikasi atas PER-175/PJ./2006 mulai 1 Maret 2007 dan kegiatan ini dilakukan secara terus menerus dan berkelanjutan sampai saat ini. Dalam program kerja tersebut, akan menetapkan target 10.000 (sepuluh ribu) kios yang akan dilakukan penyisiran, pemenuhan target ini akan menyebabkan para petugas termotivasi dalam menjalankan tugasnya.

Setelah melakukan perencanaan yang matang, kegiatan ekstensifikasi dilanjutkan pada tahap pelaksanaan. Tahap pelaporan dan pengawasan berdasarkan dengan PER-175/PJ./2006 dan PER175/PJ./2006.

Evaluasi atas Pelaksanaan Kegiatan Intensifikasi Pajak dalam Rangka Optimalisasi Penggalian Penerimaan Pajak terhadap Objek Serta Subjek Pajak yang Telah Tercatat atau Terdafar di KPP Pratama Jakarta Tanah Abang Dua

Kegiatan Intensifikasi pajak ini dilakukan dengan membenahi pembayaran pajak dari sektor ke sektor, sehingga dapat mencapai target penerimaan RAPBN 2010, yang meningkat $2 \%$ dari tahun sebelumnya sebesar Rp 295,528 Triliun, sehingga menjadi sebesar Rp 354,538 Triliun.

\section{Evaluasi atas Hambatan-Hambatan yang dihadapi}

Dalam pelaksanaan kegiatan ekstensfikasi Wajib Pajak dan Intensifikasi Pajak yang dilakukan KPP Pratama Jakarta Tanah Abang Dua belum cukup berhasil, hal ini dikarenakan adanya beberapa kendala yang mengakibatkan pencapaian hasil yang kurang optimal, hambatan-hambatan tersebut diantaranya adalah: terbatasnya sumber daya manusia, kurangnya kerjasama dengan pihak terkait dan rendahnya tingkat kesadaran wajib pajak

Tabel 3 Rasio Kepatuhan Wajib Pajak Terdaftar dan SPT yang Diterima

Pada KPP Pratama Jakarta Tanah Abang Dua Tahun 2008-2009

\begin{tabular}{lrrrrrr}
\hline SPT Tahunan & \multicolumn{2}{c}{ WP Terdaftar ${ }^{*}$ ) } & \multicolumn{2}{c}{ Penerimaan SPT } & \multicolumn{2}{c}{$\begin{array}{c}\text { Rasio } \\
\text { Kepatuhan }\end{array}$} \\
& $\mathbf{1 2 / 3 1 / 2 0 0 8}$ & $\mathbf{1 2 / 3 1 / 2 0 0 9}$ & $\mathbf{1 2 / 3 1 / 2 0 0 9}$ & $\mathbf{7 / 2 9 / 2 0 1 0}$ & $\mathbf{2 0 0 8}$ & $\mathbf{2 0 0 9}$ \\
\hline Badan & 6.075 & 6.316 & 1.160 & 1.186 & 19,09 & 18,78 \\
Orang Pribadi & 16.264 & 20.175 & 7.306 & 10.990 & 44,92 & 54,47 \\
\hline
\end{tabular}

Sumber: Sesuai SE-10/PJ./2010 Seksi PDI KPP Pratama Jakarta Tanah Abang Dua *) tidak termasuk DE (Delete) dan PL (Pindah Keluar) 
Berdasarkan Tabel 3, terlihat bahwa jumlah Wajib Pajak yang terdaftar tahun 2009 meningkat dari tahun 2008, tetapi jumlah peningkatan Wajib Pajak tersebut tidak signifikan dan diikuti dengan SPT Tahunan yang diterima. SPT Tahunan yang diterima tahun 2009 mengalami peningkatan dibandingkan tahun 2008. Pada tahun 2010 SPT Tahunan yang diterima sebanyak 10.990 SPT, jumlah ini meningkat dibandingakan dengan SPT Tahunan yang diterima tahun sebelumnya 2009 sebanyak 7.306 SPT. Jika dilihat dari prosentasi perbandingan antara jumlah SPT Tahunan yang diterima dengan jumlah Wajib Pajak terdaftar pada tahun 2009, mengalami peningkatan dibandingkan dengan tahun 2008, akan tetapi tingkat kesadaran Wajib Pajak menyampaikan SPT tidak sebanding dengan Wajib Pajak yang sudah terdaftar, hal ini dikarenakan kurangnya tingkat kesadaran Wajib Pajak untuk menyampaikan SPT Tahunan. Upaya-upaya yang dilakukan untuk mengatasi hambatan pelaksanaan ekstensfikasi Wajib Pajak dan Intensifikasi Pajak, yaitu: (1) meningkatkan penyuluhan perpajakan dan sosialisasi; (2) meningkatkan kerjasama dengan instansi atau pihak-pihak terkait; (3) pemanfaatan data internal yang akurat; (4) pemberdayaan sumber daya manusia; dan (5) sistem administrasi perpajakkan yang tepat.

\section{Hasil Pelaksanaan Ekstensifikasi Wajib Pajak dan intensifikasi pajak}

Faktor-faktor yang mempengaruhi penerimaan pajak adalah: (1) kejelasan dan kepastian Peraturan Perundang-undangan Perpajakan; (2) tingkat intelektual masyarakat; (3) kualitas petugas pajak (intelektual, keterampilan, integritas dan moral yang tinggi); (4) sistem administrasi perpajakan yang tepat.

Tabel 4 Kinerja Ekstensifikasi Wajib Pajak dalam mencapai target ber-NPWP dan Realisasi pada KPP Pratama Tanah Abang Dua Tahun 2007- April 2011

\begin{tabular}{cccccc}
\hline & \multicolumn{2}{c}{ Target } & \multicolumn{2}{c}{ Realisasi } & Persentase \\
\cline { 2 - 6 } Tahun & Karyawan & Non Karywan & Karyawan & Non Karyawan & $\%$ \\
\hline 2007 & 8799 & & 3521 & 6660 & 115 \\
2008 & 5539 & & 6148 & 2287 & 152 \\
2009 & 5282 & 1100 & 5566 & 822 & 100 \\
2010 & 472 & 1515 & 1724 & 1111 & 143 \\
2011 & 100 & 424 & 521 & & 189 \\
Jumlah & & 23231 & & $\mathbf{2 8 5 4 9}$ & \\
\hline
\end{tabular}

Sumber: Seksi Ekstensifikasi KPP Pratama Tanah Abang Dua

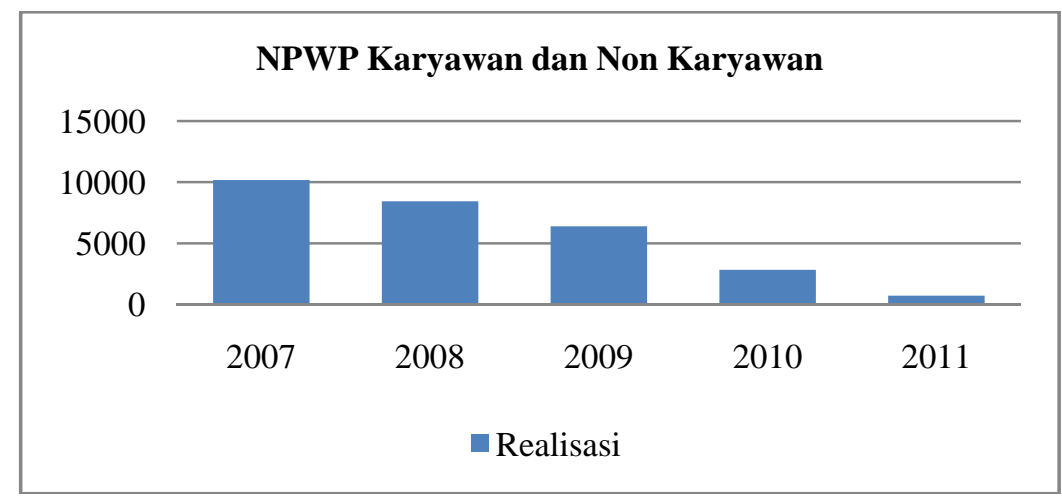

Gambar 2 NPWP Domisili Karyawan dan Non Karyawan Tahun 2007-2010 di KPP Tanah Abang Dua 
Kinerja ekstensifikasi Wajib Pajak pada tabel 4.3 diatas, menunjukkan peningkatan jumlah karyawan ber-NPWP setiap tahunnya dari tahun 2009-2011, sebelumnya pada tahun 2007-2008 target pencapaian ber-NPWP belum di kelompokkan antara karyawan dan non karyawan (pengusaha, pemilik tempat usaha di pusat perdagangan/pertokoan, penduduk yang bertempat tinggal) dan dengan adanya kebijakan dari Kanwil berdasarkan Badan Kebijakan Fiskal, maka di tahun 2009 di adakan pengelompokan target untuk karyawan dan non karyawan. Realisasi ber-NPWP mengalami peningkatan pada kategori karyawan, hal ini di sebabkan karena hampir sebagian besar karyawan yang bekerja pada perusahaan sudah terdaftar ber-NPWP sesuai dengan kebijakan pemberi kerja atau perusahaan dan di potong pajak yang terhutang atas penghasilan Wajib Pajak yang diterima setiap bulannya oleh pemberi kerja atau bendaharawan pemerintah.

Sebaliknya, realisasi pada kategori non karyawan tidak melebihi target yang di tetapkan oleh Badan Kebijakan Fiskal, hal ini di sebabkan karena hampir 70\% KPP Tanah Abang Dua berada dalam wilayah strategis untuk bisnis di pusat kota Jakarta terutama di sentra usaha di bidang perdagangan yang sebagian besar masyarakat sudah memiliki NPWP domisili sesuai dengan Kartu Tanda Pengenal (KTP) masing-masing wilayah. Penurunan ber-NPWP juga disebabkan faktor peningkatan PTKP (Pengusaha Tidak Kena Pajak) yang berpengaruh dalam pencapaian target ber-NPWP. Pada tahun 2008 PTKP yang ditetapkan sebesar Rp 13.200 .000 (sd 31 Desember 2008) menjadi Rp 15.840.000 sejak 1 Januari 2009. Hal ini, menurunkan pencapaian target ber-NPWP bagi kategori non karyawan, jika status mereka hanya sebagai pelayan pada pertokoan atau perdagangan di PGMTA (Pusat Grosir Tanah Abang Dua) maka penghasilan mereka, tidak memenuhi sebagai Wajib Pajak ber-NPWP.

\section{Kontribusi Hasil Pelaksanaan Ekstensifikasi Wajib Pajak dan intensifikasi pajak terhadap Penerimaan PPh Orang Pribadi}

Tabel 5 Rencana dan Realisasi Penerimaan PPh Orang Pribadi tahun 2007-2010 di KPP Pratama Jakarta Tanah abang Dua

\begin{tabular}{rrr}
\hline \multicolumn{1}{c}{ Tahun } & Rencana Penerimaan & Realisasi Penerimaan \\
\hline 2007 & 7.431 .383 .595 & 8.797 .933 .683 \\
2008 & 12.112 .120 .000 & 11.006 .215 .993 \\
2009 & 13.654 .457 .195 & 11.449 .644 .225 \\
2010 & 10.534 .993 .686 & 10.326 .571 .820 \\
\hline
\end{tabular}

Sumber: Seksi PDI KPP Pratama Tanah Abang Dua

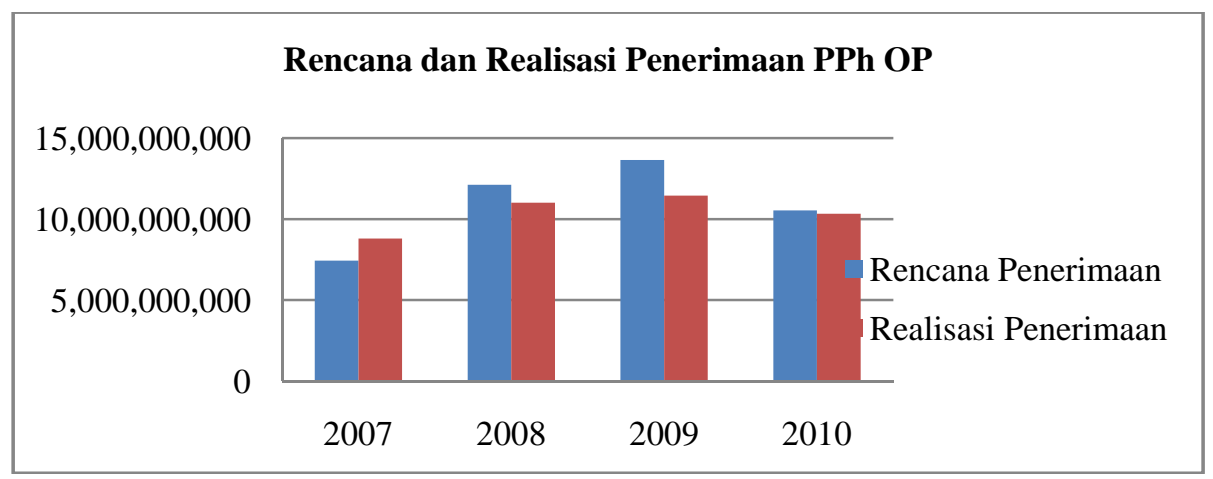

Gambar 3 Rencana dan Realisasi PPh Orang Pribadi tahun 2007-2010

Di KPP Pratama Tanah Abang Dua 


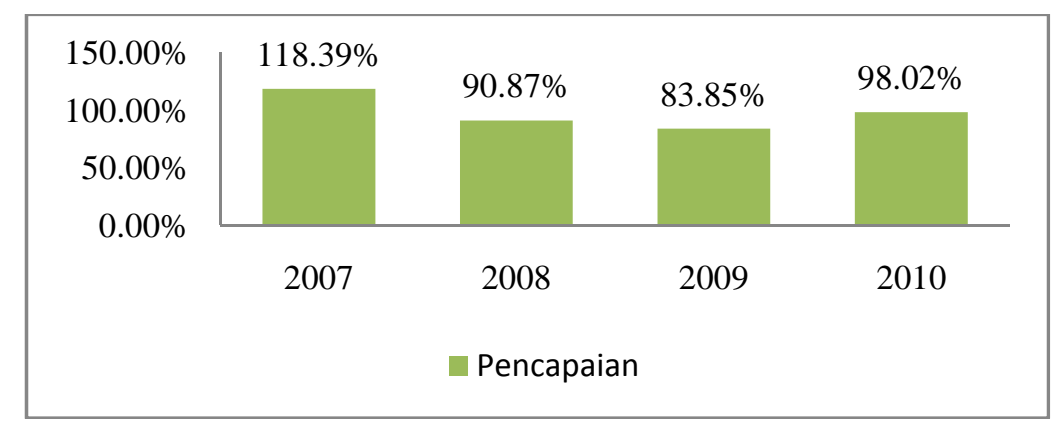

Gambar 4 Persentase Penerimaan PPh Orang Pribadi Pada tahun 2007-2010 di KPP Pratama Tanah Abang Dua

\section{PENUTUP}

Kegiatan ekstensifikasi yang dilakukan pada Kantor Pelayanan Pajak Pratama Jakarta Tanah Abang Dua, menunjukkan hasil yang belum optimal terutama dalam peningkatan jumlah Penerimaan Pajak Penghasilan Orang Pribadi. Meskipun menunjukkan angka penerimaan yang kurang maksimal, akan tetapi KPP Pratama Tanah Abang Dua telah melaksanakan kegiatan ektensifikasi Wajib Pajak dan intensifikasi pajak dengan baik, diantaranya adalah: memilih objek-objek yang memiliki potensi pajak untuk dijadikan target operasi (seperti: pusat-pusat bisnis, pemilik mobil atau dealer mobil, rumah mewah, serta karyawan) dan mengumpulkan data dari lingkungan internal DJP dalam rangka menunjang kegiatan bedah mall dan pusat bisnis lainnya, melakukan mapping terhadap objek yang dijadikan target operasi dan membandingkannya dengan database dikantor, serta mengusulkan pemeriksaan khusus terhadap Wajib Pajak yang melaporkan penghasilan dalam SPT yang belum sesuai dengan keadaan yang sebenarnya berdasarkan analisis dan data yang terdapat pada KPP. Dengan serangkaian kegiatan tersebut, diharapkan penambahan jumlah Wajib Pajak dapat diikuti dengan pemenuhan kewajiban perpajakan oleh Wajib Pajak. Dalam rangka menambah jumlah Wajib Pajak Orang Pribadi yang terdaftar, KPP Pratama Jakarta Tanah Abang Dua melakukan kegiatan ekstensifikasi Wajib Pajak Orang Pribadi melalui canvassing sesuai dengan Program Kegiatan PER175/PJ./2006 (Pasal 1, nomor 2) dan Program Kegiatan PER-16/PJ./2007. Program canvassing dimulai tanggal 1 Maret 2007, dengan menyisiri berbagai lokasi potensial Wajib Pajak yang belum ber-NPWP. Kegiatan canvassing ini memiliki tujuan utama untuk memberikan penyuluhan perpajakan guna lebih menyadarkan para Wajib Pajak tentang kewajiban perpajakannya. Tidak lupa, melaksanakan program intensifikasi pajak guna mengamankan target penerimaan pajak.

Di tahun 2010, sejumlah upaya seperti safeguard mechanism sudah diterapkan oleh KPP Pratama Tanah Abang Dua, salah satunya dari kegiatan safeguard mechanism adalah intensifikasi pajak atau penggalian potensi pajak terpadu yang dimulai dari kegiatan mapping, benchmarking dan profiling, dengan melakukan analisis terhadap sektor-sektor yang terdapat pada kontribusi suatu wilayah (misal: kabupaten atau kota) ataupun sektor-sektor yang terdapat pada kontribusi penerimaan pajak suatu kantor pelayanan pajak atau kantor wilayah Direktorat Jenderal Pajak. Mengingat wilayah kerja KPP Pratama Jakarta Tanah Abang Dua berada di daerah perekonomian dan sentra usaha strategis serta masih banyak penduduk yang belum ber-NPWP, memberikan peluang lebih besar bagi KPP dalam menjaring masyarakat untuk dijadikan Wajib Pajak dengan memberikan NPWP. Namun dalam pelaksanaannya KPP Pratama Tanah Abang Dua harus dapat membaca keadaan dan mengantisipasi berbagai keadaan yang mungkin akan menjadi masalah dalam kelancaran kegiatan ekstensifikasi Wajib Pajak, seperti mutasi penduduk tanpa keterangan perubahan tempat domisili calon Wajib Pajak dari pihak yang berwenang dan perubahan kondisi sosial masyarakat. 
Hambatan-hambatan yang dihadapi dalam pelaksanaan kegiatan ekstensifikasi Wajib Pajak dan Intesifikasi Pajak Orang Pribadi adalah: (1) terbatasnya SDM Seksi Ekstensifikasi di KPP Pratama Jakarta Tanah Abang Dua yang hanya berjumlah 5 (lima) pegawai, sedangkan jumlah Wajib Pajak dan wilayah serta lingkup pekerjaan yang ditangani cukup banyak dan luas; (2) masih kurangnya kerjasama yang terpadu dengan pihak-pihak terkait seperti pemerintah daerah, pengelola perumahan mewah, pengelola pusat bisnis, asosiasi pengusaha atau pedagang dan sebagainya; (3) kurangnya data baik intern maupun extern yang lengkap dan mutakhir mengenai data Wajib Pajak dan potensi pengusaha; (4) kurangnya kesadaran subjek pajak untuk memiliki NPWP karena masih banyak dari mereka yang menganggap bahwa NPWP merupakan beban, selain membayar pajak juga wajib melaporkan pembayaran tersebut ke KPP; (5) kurang kondusifnya situasi perekonomian Negara yang mempengaruhi kesejahteraan masyarakat.

Upaya-upaya yang dilakukan sebagai solusi dalam mengatasi hambatan pelaksanaan kegiatan ekstensifikasi Wajib Pajak, yaitu: (1) meningkatkan penyuluhan perpajakan dan sosialisasi secara berkelanjutan baik secara langsung maupun melalui media massa; (2) diupayakan meningkatkan kerjasama yang terpadu dengan pihak terkait secara terus-menerus; (3) pemanfaatan data internal dan data external untuk memperoleh data calon Wajib Pajak serta pemutakhiran data internal dengan keadaan sesungguhnya untuk dasar pelaksanaan ekstensifikasi masa berikutnya; (4) pelaksanaan kegiatan intensifikasi pajak dengan melakukan himbauan kepada Wajib Pajak baru agar patuh dalam memenuhi kewajiban perpajakannya; dan (5) pemberdayaan SDM melalui penambahan personil dan pelatihan teknis ekstensifikasi dan intensifikasi pelayanan pajak guna menigkatkan kinerja KPP.

Program kegiatan ekstensifikasi Wajib Pajak dan intensifikasi pajak yang telah dilakukan oleh Seksi Ekstensifikasi dibantu Account Representative di KPP Pratama Jakarta Tanah Abang Dua tersebut telah dilaksanakan dengan baik dan terencana sesuai dengan prosedur yang terdapat didalam masing-masing peraturan. Kegiatan ekstensfikasi Wajib Pajak dan intensifikasi pajak yang telah dilakukan menghasilkan jumlah Wajib Pajak, untuk tahun 2010 sebanyak 31.819 Wajib Pajak Orang Pribadi terdaftar dan 22.015 Wajib Pajak Orang Pribadi yang efektif (Data per 1 Januari 2010) pada KPP Pratama Jakarta Tanah Abang Dua. Tingkat kesadaran Wajib Pajak baru pada KPP Pratama Jakarta Tanah Abang Dua yang terdaftar untuk memenuhi kewajiban perpajakannya setelah diberikan NPWP mengalami peningkatan tetapi tidak signifikan, terutama dalam hal melaporkan SPT. Pada tahun 2008 Wajib Pajak Orang Pribadi yang melaporkan SPT hanya sebesar 44, 92\% dari Wajib Pajak Orang Pribadi yang terdaftar dan pada Tahun 2009 Wajib Pajak Orang Pribadi yang melaporkan SPT sebesar 54, 47\%. SPT, mengalami peningkatan yaitu sebesar 9, 55 \% dari Wajib Pajak Orang Pribadi yang terdaftar.

Tabel 6 Perbandingan Pertumbuhan Penerimaah PPh Orang Pribadi tahun 2007-2008

\begin{tabular}{rrrr}
\hline Realisasi 2007 & Realisasi 2008 & Surplus (Defisit) & \multicolumn{1}{c}{ Growth } \\
\hline 8.797 .933 .683 & 11.006 .215 .993 & 2.208 .282 .310 & $25,10 \%$
\end{tabular}

\begin{tabular}{cccc}
\hline Realisasi 2008 & Realisasi 2009 & Surplus (Defisit) & Growth \\
\hline 11.006.215.993 & 11.449 .644 .225 & 443.428 .232 & $4,03 \%$ \\
\hline Realisasi 2009 & Realisasi 2010 & Surplus (Defisit) & Growth \\
\hline 11.449.644.225 & 10.326 .571 .820 & 1.123 .072 .405 & $-9,81 \%$ \\
\hline
\end{tabular}


Hasil pelaksanaan kegiatan ekstensifikasi dan intensifikasi tersebut yang terlihat dari tabel 5.1. menunjukkan hasil yang kurang optimal dalam memberikan kontribusi terhadap peningkatan penerimaan penghasilan Orang Pribadi. Pada tahun 2007 Realisasi penerimaan PPh Orang Pribadi setahun yaitu sebesar Rp. 8.797.933.683. penerimaan tersebut mengalami peningkatan atau growth sebanyak 25,10\% dari Realisasi Penerimaan PPh OP tahun 2008 yaitu sebesar Rp. 11.006.215.993. tetapi pertumbuhan penerimaan $\mathrm{PPh}$ OP tahun 2008 mengalami penurunan sebesar 4,03\% dari penerimaan PPh OP tahun 2009 yaitu sebesar Rp 11.449.644.225. Meskipun jumlah WP Orang pribadi meningkat pada tahun sebelumnya, tetapi kontribusi yang diberikan WP Orang Pribadi kepada Penerimaan PPh Orang Pribadi menurun, sebesar Rp. 1.123.072.405 pada tahun 2010 atau $-9,81 \%$. Penurunan ini dipengaruhi oleh beberapa faktor seperti rendahnya tingkat kepatuhan Wajib Pajak dalam memenuhi kewajiban perpajakannya, kondisi perekonomian Negara yang menurun sehingga mempengaruhi penghasilan Wajib Pajak dalam membayar PPh Orang Pribadi, serta di pengaruhi oleh program sunset policy yang mempunyai periode waktu sampai dengan 31 Desember 2008 dan penghapusan sunset policy menimbulkan penurunan peneriman PPh Orang Pribadi pada tahun 2010 dengan angka yang negative.

\section{Saran}

Upaya-upaya ekstensifikasi Wajib Pajak dan Intensifikasi pajak yang dilaksanakan oleh setiap KPP sebaiknya terus menerus dikembangkan terutama dalam melakukan kerjasama dengan instansi terkait, baik dari intern DJP maupun instansi extern DJP dengan tujuan membantu DJP untuk melakukan upaya penyadaran bagi Wajib Pajak. Dalam pencapaian target penerimaan pajak, pihak fiskus harus memverifikasi Wajib Pajak baru yang memiliki Nomor Pokok Wajib Pajak. Aparat pajak juga perlu untuk meningkatkan kedisiplinan, dedikasi dan kejujuran, tidak mendatangani kediaman Wajib Pajak tanpa surat tugas, serta menghindarkan diri dari perbuatan yang melanggar hukum dan undang-undang. Untuk mendapatkan data-data yang dibutuhkan dari instansi extern, pihak KPP hendaknya melakukan pendekatan secara langsung dan berkesinambungan dengan para pejabat yang berwenang dalam instansi atau perusahaan dengan memberikan jaminan bahwa data yang diminta oleh KPP hanya akan digunakan untuk keperluan perpajakan dengan tetap memperhatikan dan menjamin kerahasiaan perusahaan serta kode etik antar instansi. KPP hendaknya terus meningkatkan kegiatan penyuluhan Wajib Pajak termasuk tentang tata cara pendaftaran WP dan cara pengisian SPT melalui kegiatan visiting (Terjun langsung ke perumahan Wajib Pajak), sosialisasi dan himbauan langsung kepada Wajib Pajak.

KPP harus lebih meningkatkan kualitas pelayanan kepada Wajib Pajak, baik dalam penambahan fasilitas, keramahan pelayanan, termasuk dalam menampung kritik dan keluhan Wajib Pajak sehingga upaya untuk memperbanyak Wajib Pajak tidak sia-sia, serta diupayakan juga kemudahan-kemudahan bagi Wajib Pajak untuk memenuhi kewajibannya, kemudahan dalam pengisian SPT, Pembayaran pajak dan sebagainya. KPP harus lebih konsisten dalam penegakkan hukum (law enforcement) dengan pemberian sanksi baik berupa denda, bunga, kenaikan maupun sanksi pidana terutama bagi Wajib Pajak yang tidak kooperatif dan lalai dalam memenuhi kewajiban perpajakannya. Penegakkan hukum yang tegas juga harus dilaksanakan kepada para Fiskus dan para pejabat pajak yang melakukan tindakan penggelapan dan korupsi pajak berupa pemberian sanksi denda maupun tindak pidana kurungan sesuai dengan perbuatannya. 


\section{DAFTAR PUSTAKA}

Direktorat Jenderal Pajak. (2003). Surat Edaran Direktur Jendral Pajak: S - 456/PJ.731/2003 tentang Pelaksanaan Ekstensifikasi dan Intensifikasi.

Direktorat Jenderal Pajak. (2004). Surat Edaran Direktur Jendral Pajak: SE - 06/PJ.7/2004 tentang Pemeriksaan Sederhana Lapangan Dalam Rangka Ekstensifiksi WP.

Direktorat Jenderal Pajak. (2006). Peraturan Direktur Jenderal Pajak: PER - 175/PJ./2006 tentang Tata Cara Pemutakhiran Data Objek Pajak Dan Ekstensifikasi Wajib Pajak Orang Pribadi yang melakukan kegiatan Usaha Dan/Atau Meiliki Tempat Usaha di Pusat Perdagangan Dan/Atau Pertokoan.

Direktorat Jenderal Pajak. (2007). Peraturan Direktur Jenderal Pajak: PER - 116/PJ./2007 tentang Ekstensifikasi Wajib Pajak Orang Pribadi melalui Pendataan Objek Pajak PBB.

Direktorat Jenderal Pajak. (2007). Surat Edaran Direktur Jendral Pajak: SE - 13/PJ/2007 tentang Penjelasan Peraturan DIRJEN PAJAK: PER-175/PJ./2006 tentang Tata Cara Pemuktahiran Data Objek Pajak Dan Ekstensifikasi Wajib Pajak Orang Pribadi yang Melakukan Kegiatan Usaha Dan/Atau Memiliki Tempat Usaha Di Pusat Perdagangan Dan/Atau Pertokoan.

Direktorat Jenderal Pajak. (2007). Surat Edaran Direktur Jendral Pajak: SE - 26/PJ.01/2007 tentang Standar Biaya Pelaksanaan Kegiatan Ekstensifikasi WP Orang Pribadi. 